\title{
Beryllium-Aluminum Alloy
}

National Cancer Institute

\section{Source}

National Cancer Institute. Beryllium-Aluminum Alloy. NCI Thesaurus. Code C45884.

A crystalline, inorganic compound composed of beryllium and aluminum in which beryllium increases the alloys thermal and electrical conductivity and emits toxic fumes of beryllium oxides upon heating. Beryllium-aluminum alloy is mainly used in light aircraft construction. Inhalation exposure to its dust and fumes irritates the nose, throat and lungs and can cause pneumonitis. Prolonged exposure can result in a chronic beryllium disease called berylliosis causing granuloma and fibrosis formation in the lungs. Beryllium is associated with an increased risk of developing lung cancer. ( $\mathrm{NCl05)}$ 